\title{
High-grade neuroendocrine carcinoma of the cervix uteri
}

INSERM

\section{Source}

INSERM. (1999). Orphanet: an online rare disease and orphan drug data base. Highgrade neuroendocrine carcinoma of the cervix uteri. ORPHA:213777

High-grade neuroendocrine carcinoma of the cervix uteri is a rare, aggressive, primary cervical neoplasm, originating from neuroendocrine cells present in the lining epithelium of the cervix, characterized, macroscopically, by usually large lesions, sometimes with a barrel-shaped appearance. Patients often present with abnormal vaginal bleeding or discharge, pelvic/abdominal pain, post-coital spotting and/or dysuria, while symptoms related to carcinoid syndrome are not frequent. 